\title{
Allodiaptomus nongensis, a new diaptomid copepod (Copepoda: Calanoida) from a tributary of the Mekong River, with notes on its consumption by local people in Central Laos
}

\author{
La-orsri SANOAMUANG, ${ }^{1,2 *}$ Santi WATIROYRAM ${ }^{3}$ \\ ${ }^{1}$ Applied Taxonomic Research Center, Faculty of Science, Khon Kaen University, Khon Kaen 40002; ${ }^{2}$ International College, Khon \\ Kaen University, Khon Kaen 40002; ${ }^{3}$ Division of Biology, Faculty of Science, Nakhon Phanom University, Nakhon Phanom 48000 , \\ Thailand
}

\begin{abstract}
A new calanoid copepod, Allodiaptomus nongensis n. sp., is herein described based on samples collected from the Xe Lanong River (a tributary of the Mekong River), and 13 other localities in Central Laos. This is the sixth species of the genus Allodiaptomus Kiefer, 1936. The other five members in the genus were recorded from India, South China, Cambodia, Thailand, and Vietnam. The features that stand out in the new species are in the male: the right caudal ramus has a large, biacuminate, conical process proximally, and the Exp-2 of the right P5 has a hook-shaped principal spine proximally. The new species is abundant in both temporary and permanent waters, but is restricted to Savannakhet Province. This Laotian endemic copepod is referred to by local people as "Pa Khayong", which means tiny fish. Since high densities of this copepod can be found in the dry season (December until May), several man-made copepod traps are placed by local people along the river banks in Muang Nong District. Interestingly, large concentrations of individuals (body length: $\sim 1 \mathrm{~mm}$ ) belonging to the new species are harvested and consumed by these villagers. Additional information about this species and the copepod fisheries by local people in this area is provided herein. In this paper, the reassignment of Allodiaptomus rarus to the genus Mongolodiaptomus is proposed.
\end{abstract}

\section{INTRODUCTION}

The genus Allodiaptomus Kiefer, 1936 is a small group of freshwater diaptomid copepods (Copepoda, Calanoida, Diaptomidae) that consists of five known species (Ranga Reddy et al., 2000; Walter and Boxshall, 2018), distributed mainly in river systems, reservoirs, and fish ponds (Ranga Reddy, 1987). Four species have been found in India, including A. mirabilipes Kiefer, 1936, A. satanas (Brehm, 1952), A. intermedius Ranga Reddy, 1987, and A. raoi Kiefer, 1936. A. raoi was also found in

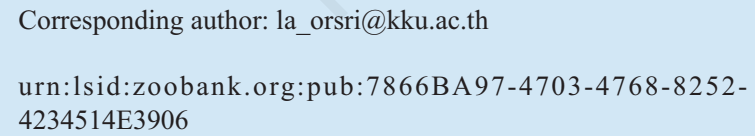

Key words: Copepod fisheries; edible copepod; Laotian endemic; Southeast Asia; Xe Lanong River.

Edited by: Federico Marrone, University of Palermo, Italy

Received: 20 December 2018.

Accepted: 6 March 2019.

This work is licensed under a Creative Commons Attribution NonCommercial 4.0 License (CC BY-NC 4.0).

${ }^{\circ}$ Copyright: the Author(s), 2019

Licensee PAGEPress, Italy

J. Limnol., 2019; 78(2): 185-200

DOI: 10.4081/jlimnol.2019.1884
Cambodia, Thailand, South China, and Vietnam (Kiefer, 1936, Brehm, 1952; Ranga Reddy, 1987, 1994; Ranga Reddy and Das, 1981; Ranga Reddy et al., 1998; Sanoamuang, 1999, 2002; Lin and Han, 2012; Kulkarni and Pai, 2016; Tran et al., 2016). The fifth species, $A$. mieni Dang and Ho, 1985 has so far been reported only in Vietnam (Phan et al., 2015).

According to the taxonomic revision by Ranga Reddy et al. (2000), the genus Allodiaptomus can be distinguished from the closely allied genera Neodiaptomus Kiefer, 1932 and Mongolodiaptomus Kiefer, 1938 by the armature of the second exopodsegment of the right fifth leg in males. In Allodiaptomus, that second exopod has at least two lateral spines, and the principal one is proximally located, whereas the other one(s) is/are distally situated; no mid-lateral spine is present. In Mongolodiaptomus, the second exopod has two or three lateral spines (or spinous processes), but the principal one is located on the mid-outer margin, whereas the small spinous process(es) occurs/occur proximally as well as distally. In Neodiaptomus, the second exopod has only one single lateral spine that inserts either proximal or somewhat median. As a consequence of this revision, three species previously recognized as $A$. gladiolus Shen and Lee, 1963; A. pectinidactylus Shen and Tai, 1964; and, A. calcarus Shen and Tai 1965, have been transferred to the genus Mongolodiaptomus (Ranga Reddy et al., 2000; Sanoamuang and Watiroyram, 2018).

Little is known about the biodiversity of freshwater zooplankton in Laos. Only three articles have been published on calanoid copepods during the last 15 years 
(Sanoamuang and Sivongxay, 2004; Kottelat, 2007; Sanoamuang and Watiroyram, 2018). During a sampling survey conducted from 2001 to 2003 that investigated the biodiversity of freshwater copepods from 5 provinces of Central Laos, an undescribed copepod was discovered. In this paper, we describe the new species of Allodiaptomus from the Xe Lanong River and other 13 habitats in Savannakhet Province, Central Laos, and compare its relationship with its congeners. Additional information on the copepod fisheries by local people in Muang Nong District, Savannakhet Province is also provided.

\section{METHODS}

\section{Study area and sampling}

Laos is the only Southeast Asian country without direct access to the sea. It shares borders with Thailand, Myanmar, China, Vietnam, and Cambodia. The Mekong River forms the country's western border with Thailand, the Annamite mountains form its eastern border with Vietnam, Cambodia is to the south, and China and Myanmar are to the northwest. The main geographic features of the country are its mountains and the Mekong River valley. Laos has a tropical, monsoon climate with only two distinctive seasons - a dry season and a wet season. The dry season begins in November and lasts until
May, with the cooler period beginning in December until February. The rainy season starts in June and lasts until October, and rainfall varies according to altitude. The amount of rainfall is normally comprised between 1200 and $2200 \mathrm{~mm}$ per year in the plains, and may exceed 3000 $\mathrm{mm}$ on the most exposed mountain slopes. The country is divided into three geographical areas: the northern, central, and southern parts.

Sampling was conducted in 5 provinces (Vientiane, Vientiane Capital, Bolikhamxay, Khammouane, and Savannakhet) of Central Laos (Fig. 1A) during 20012003. A total of 209 qualitative samples from 103 localities were collected using a plankton net with a mesh size of $60 \mu \mathrm{m}$ from a variety of waterbodies, such as ponds, swamps, reservoirs, lakes, rivers, roadside canals, rice fields, and buffalo wallows. The samples were preserved in $70 \%$ ethanol or $4 \%$ formaldehyde immediately after collection.

One of the main sampling areas for this study was Xe Bang Hieng River, a major tributary of the Mekong. The Xe Bang Hieng River Basin covers most of Savannakhet Province. The water of this river flows from the LaosVietnam border to the Mekong at a point about $90 \mathrm{~km}$ downstream of Savannakhet Province. The river has a length of $370 \mathrm{~km}$ and a basin area of $19,223 \mathrm{~km}^{2}$. Its main tributaries are the Xe Lanong, Xe Pon, Xe Thamouak, Xe Xangxoy, and Xe Champhon Rivers (Fig. 1B).

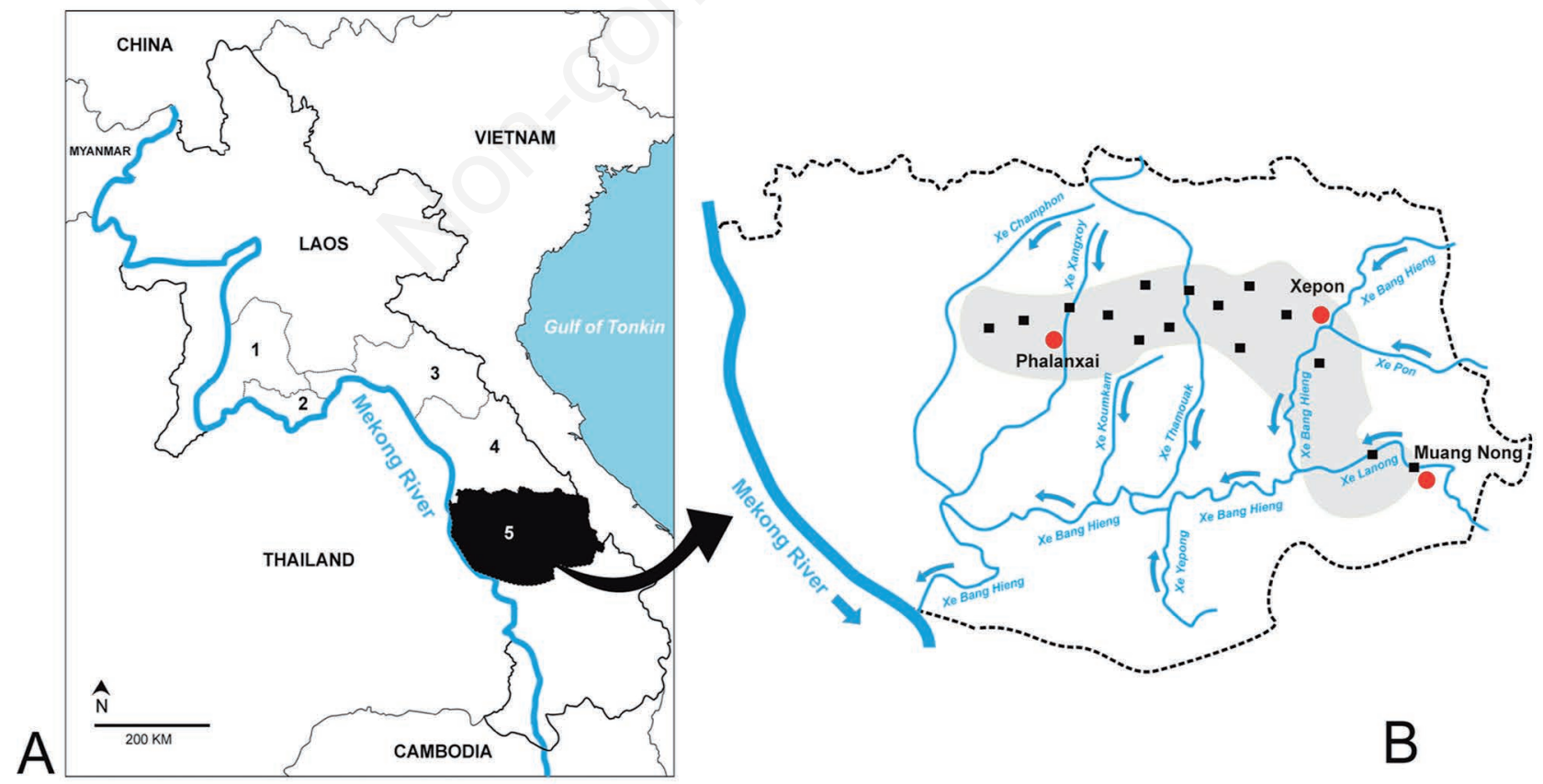

Fig. 1. A) The study area in 5 provinces of Central Laos: 1, Vientiane Province; 2, Vientiane Capital; 3, Bolikhamxay Province; 4, Khammouane Province; 5, Savannakhet Province (black area); --, provincial border. B) Enlargement of Savannakhet Province: gray shaded area, distributional area of Allodiaptomus nongensis, new species; black spots, sampling sites. 


\section{Identification}

Specimens were dissected and mounted at 40-100x magnification under an Olympus SZ51 stereomicroscope. All appendages and body ornamentation were examined at 1,000x magnification under an Olympus compound microscope (CX31). All drawings were made at 1,000x magnification under compound microscope with a drawing tube (Olympus U-DA). The final versions of the drawings were made using CORELDRAW ${ }^{\circledR} 12.0$ graphic program. Specimens for scanning electron microscopy (SEM) were dehydrated in an ethanol series $(50 \%, 70 \%$, $80 \%, 90 \%, 95 \%, 100 \%, 100 \%, 50: 50 \mathrm{v} / \mathrm{v}$ of absolute ethanol: amyl acetate, and $100 \%$ amyl acetate) for $15 \mathrm{~min}$ for each concentration. SEM photographs were taken using a scanning electron microscope (LEO, 1450VP) after drying and gold-coating the specimens.

The following abbreviations are used throughout the text and figures: Pdg n, pediger n; Ur n, urosomite n; Enp, endopod; Exp, exopod; Exp/Enp-n, exopodal segment n/endopodal segment n; P1-P5, swimming legs 1-5; A, aesthetasc; S, setae; and, Sp, spine. The nomenclature and descriptive terminology follow Huys and Boxshall (1991). Specimens were deposited at the Natural History Museum, London, United Kingdom (NHMUK); the Faculty of Science, Nakhon Phanom University, Thailand (NPU); and, the Applied Taxonomic Research Center, Khon Kaen University, Thailand (KKU).

\section{RESULTS}

A total of 19 calanoid species was identified from the 209 qualitative samples (103 localities), including a new species, Allodiaptomus nongensis n. sp. The species diversity of calanoid copepods of Laos from these collections will be published elsewhere. Information on the copepod fishery exerted by local people in Savannakhet Province, and a description of the new species are provided here.

\section{Description of the new species}

The description of Allodiaptomus nongensis n. sp. is presented herein.

\section{Order Calanoida Sars, 1903}

Family Diaptomidae Baird, 1850

Genus Allodiaptomus Kiefer, 1936

Allodiaptomus nongensis, new species (Figs. 2 to 9)

\section{Type locality}

Xe Lanong River at Muang Nong District, Savannakhet Province, Central Laos; $16^{\circ} 22^{\prime} 54^{\prime \prime} \mathrm{N} ; 106^{\circ}$ $28^{\prime} 54^{\prime \prime}$ E.

\section{Type material}

Holotype, one adult male (NHMUK 2019.1), dissected and mounted in glycerol on one slide; Allotype, one adult female (NHMUK 2019.2), dissected and mounted in glycerol on one slide; Paratypes, two adult females and two adult males (NHMUK 2019.3-6), five adult females and five adult males (NPU 2018-020), five adult females and five adult males (KKU-COP-2018-S02 ), undissected and preserved in $70 \%$ ethanol in $1.5 \mathrm{~mL}$ microtubes. All specimens collected on February 2, 2003 by L. Sanoamuang. Water temperature $26.9^{\circ} \mathrm{C}, \mathrm{pH} 9.1$, conductivity $69.9 \mathrm{mS} \mathrm{cm}^{-1}$.

\section{Other localities}

(1) Nonyang Reservoir, Phin District, Savannakhet Province, 3 November 2001. Water temperature $29.5^{\circ} \mathrm{C}, \mathrm{pH} 9.5$, conductivity $104.6 \mathrm{mS} \mathrm{cm}^{-1}$.

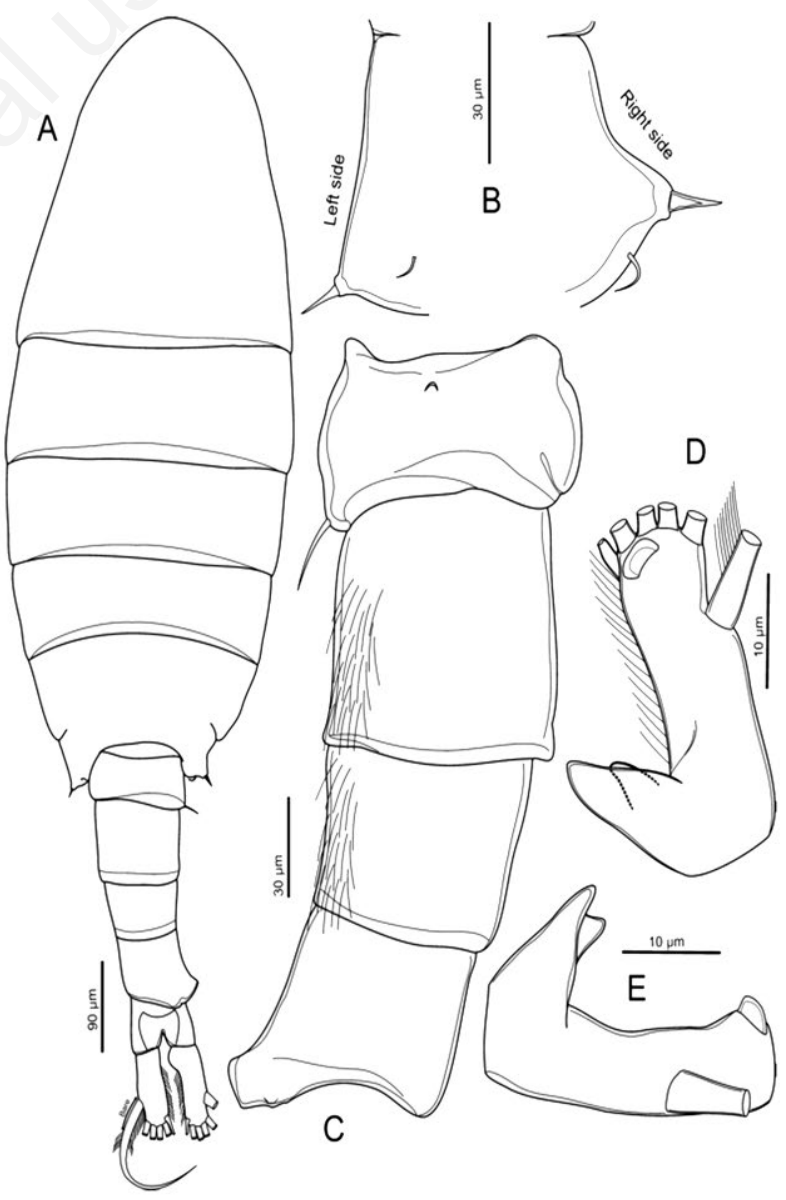

Fig. 2. Allodiaptomus nongensis, new species, male: A) habitus, dorsal view; B) lateral wings on Pdg 5; C), urosomites 1-4, ventral view; D) the right caudal ramus, ventral view; E) the right caudal ramus, lateral view. 
(2) Oudomxay Canal, Ban Oudomxay District, Savannakhet Province, 3 November 2001. Water temperature $29.0^{\circ} \mathrm{C}, \mathrm{pH} 9.3$, conductivity $72.7 \mathrm{mS} \mathrm{cm}^{-1}$.

(3) Permanent pond, Ban Phonxai District, Savannakhet Province, 3 November 2001. Water temperature $34.3^{\circ} \mathrm{C}$, pH 8.4 , conductivity $34.2 \mathrm{mS} \mathrm{cm}^{-1}$.

(4) Swamp, Ban Kok Hai District, Savannakhet Province, 3 November 2001 . Water temperature $28.8^{\circ} \mathrm{C}, \mathrm{pH} 9.1$, conductivity $101.2 \mathrm{mS} \mathrm{cm}^{-1}$.

(5) Temporary pond, Ban Sibounheuang District, Savannakhet Province, 3 February 2003. Water temperature $26.1^{\circ} \mathrm{C}, \mathrm{pH} 9.7$, conductivity $102.5 \mathrm{mS} \mathrm{cm}^{-1}$.

\section{Etymology}

The specific name nongensis refers to the place "Muang Nong District" where the new species was first recognized. A name with the Latin suffix "-ensis" is an adjective for place.

\section{Description of adult male}

Body length excluding caudal setae $0.91 \pm 0.04 \mathrm{~mm}$ (mean $\pm \mathrm{SD}, \mathrm{n}=20$ ) (Fig. 2A), smaller than female. Pdg 4 without dorsal row of spinules along posterior margin, incompletely fused to pdg 5. Lateral wing (Figs. 2 A-B and 4A) slightly asymmetrical, right apical spine stronger than opposite spine; with dorsal sensilla distolaterally, right sensilium larger than left one. Urosome (Figs. 2 A,C and 4 A,D) asymmetrical, oriented obliquely posteriad to right side: genital somite shortest, asymmetrical, right side dilated postero-laterally; with small seta on outer distal corner. Ur 2-3 symmetrical with long hairs ventrolaterally on right side. Ur 4 with right posterolateral dilated. Anal somite (Figs. 2A and 4C) asymmetrical, right side located inferior to opposite side, weakly developed operculum. Caudal rami (Figs. 2 D-E and 4 CE) asymmetrical, more than 2.0 times longer than wide, setation similar to those in female. Ventral surface of right ramus with one large, biacuminate, conical process proximally, inner tip larger than outer one; one semicircular ridge above insertion of seta IV and $\mathrm{V}$.

Right antennule (Figs. 3A and 4F) transformed and geniculate, 22-segmented.

Setal formula: 1(1S+1A), 2(3S+1A), 3(1S+1A), 4(1S), $5(2 \mathrm{~S}+1 \mathrm{~A}), \quad 6(1 \mathrm{~S}), \quad 7(1 \mathrm{~S}+1 \mathrm{~A}), \quad 8(1 \mathrm{~S}+\mathrm{Sp}), \quad 9(2 \mathrm{~S}+1 \mathrm{Sp})$, $10(1 \mathrm{~S}+1 \mathrm{Sp}), 11(1 \mathrm{~S}+1 \mathrm{Sp}), 12(1 \mathrm{~S}+1 \mathrm{~A}), 13(1 \mathrm{~S}+1 \mathrm{~A}+1 \mathrm{Sp})$, $14(2 \mathrm{~S}+2 \mathrm{~A}+1 \mathrm{Sp}), \quad 15(2 \mathrm{~S}+1 \mathrm{~A}+1 \mathrm{Sp}), \quad 16(2 \mathrm{~S}+1 \mathrm{~A}+1 \mathrm{Sp})$, $17(1 \mathrm{~S}+1 \mathrm{Sp}), 18(1 \mathrm{~S}+1 \mathrm{Sp}), 19(2 \mathrm{~S}+1 \mathrm{~A}+1 \mathrm{Sp}), 20(3 \mathrm{~S}+1 \mathrm{Sp})$, $21(2 \mathrm{~S}), 22(5 \mathrm{~S}+1 \mathrm{~A})$. Segment 20 (antepenultimate) with comb-like process (5-8 teeth, $\mathrm{n}=20)$.

Left antennule, antenna, mouthparts, and P1-P4 as in female.

P5 (Figs. 3 B-C and 5 A-I) asymmetrical, right leg highly enlarged. Intercoxal plate produced into strong finger-like process on distal margin (Fig. 5 A,D). Right leg: coxa with spinous process on distal inner of posterior lobe, located close to spine; coxal spine strong, shorter than half of basis (Fig. 5D). Basis with small median semi-circular hyaline lamella at inner margin and small seta at distal outer margin; small prominence (of variable shape) situated on disto-lateral margin (Figs. 3C and 5C). Exp-1 with acute spinous process at distal outer corner and semi-circular prominence at distal inner margin in posterior view (Figs. 3C and $5 \mathrm{H}-\mathrm{I}$ ). Exp-2 quadrangular, about 2.0 times as long as wide (Fig. 5 H-I): with articulated principal spine and two semi-circular prominences proximally, and small outer spinous process distally, unarticulated. Principal spine slender, hookshaped, shorter than half of Exp-2. End claw sickle-shaped, relatively thickened with finely serrated inner margin in the distal half of Exp-2. Enp tapering distally, small and short, not beyond insertion of principal spine; tipped with row of spinules. Left leg: coxa with slender setiform spine on posterior lobe at distal inner margin, reaching half of basis (Figs. 3C and 5E). Basis with longitudinal hyaline lamella on inner margin; with thin posterolateral seta on posterior surface, shorter than half of Exp-1 (Figs. 3 B-C and 5E). Exp 2-segmented (Figs. 3 B-C and 5E-G): Exp-1 gradually tapering in posterior end, pilose on medial margin distally; Exp-2 oval, smaller than Exp-1, with inner robust seta and serrate margin; apical process stretched into spearheadlike. Enp 1-segmented, slightly longer than Exp-1, tipped with spinules distally (Figs. 3 B-C and 5 E-G).

\section{Description of adult female}

Total body length excluding caudal setae $1.03 \pm 0.03 \mathrm{~mm}$ (mean $\pm \mathrm{SD}, \mathrm{n}=20$ ) (Fig. 6A). Rostrum with two teeth-like process anteriorly (Fig. 6B). Incomplete suture present dorsally between Pdg 4 and Pdg 5, without row of spinules or hairs dorsally. Lateral wings on Pdg 5 asymmetrical (Figs. 6A and $7 \mathrm{~A}-\mathrm{B}$ ): right wing bifid, left wing round, longer than opposite spine (extending to left genital spine); tipped with pair of strong posterior spines; each wing with dorsal spine, similar size to posterior spine. Genital doublesomite asymmetrical (Figs. 6 C,D and 7B): right side with small postero-laterally directed process, tipped with strong spine; left side with strong outward spine on prominence proximally, located slightly superior to opposite spine; genital field as in Fig. 6D, situated mid-ventrally in proximal half. Ur 2 symmetrical, shorter than wide. Anal somite symmetrical, slightly as long as wide (Fig. 6A); with weakly developed operculum.

Caudal rami (Figs. 6A and 7C) symmetrical, about two times as long as wide, with setulose margins. Caudal setae (seta II-VI) plumose except dorsal (seta VII) seta: anterolateral (II) seta largest, with bare region on outer 
margin proximally; dorsal seta (VII) articulated, thinnest, and longest.

Antennule (Fig. 6E) symmetrical, 25-segmented, extending beyond caudal setae. Setal formula, as follows: 1(1S+1A), 2(3S+1A), 3(1S+1A), 4(1S), 5(1S+1A), 6(1S), $7(1 \mathrm{~S}+1 \mathrm{~A}), \quad 8(1 \mathrm{~S}+1 \mathrm{Sp}), \quad 9(2 \mathrm{~S}+1 \mathrm{~A}), \quad 10(1 \mathrm{~S}), \quad 11(1 \mathrm{~S})$, $12(1 \mathrm{~S}+1 \mathrm{~A}+1 \mathrm{Sp}), 13(1 \mathrm{~S}), 14(1 \mathrm{~S}+1 \mathrm{~A}), 15(1 \mathrm{~S}), 16(1 \mathrm{~S})$, 17(1S), 18(1S), 19(1S+1A), 20(1S), 21(1S), 22(2S), 23(2S), 24(2S), 25(5S+1A).

Antenna (Fig. 8A) coxa with 1 inner seta. Basis with
2 inner setae on distal corner. Exp 7-segmented: Exp1-7 with 1, 3, 1, 1, 1, 1, 4 setae, respectively. Enp 2segmented: Enp-1 with 2 setae on medial margin, Enp-2 with 9 medial and 7 apical setae.

Mandible (Fig. 8B) coxa with 7 teeth on gnathobase, one small dorsal seta on distal corner. Basis with 4 inner setae. Enp 2-segmented, with 4 and 9 setae, respectively. Exp 4-segmented, with 1,1,1,3 setae, respectively.

Maxillule (Fig. 8C) praecoxal arthrite with 10 spiniform setae. Coxal endite with 4 setae, epipodite with

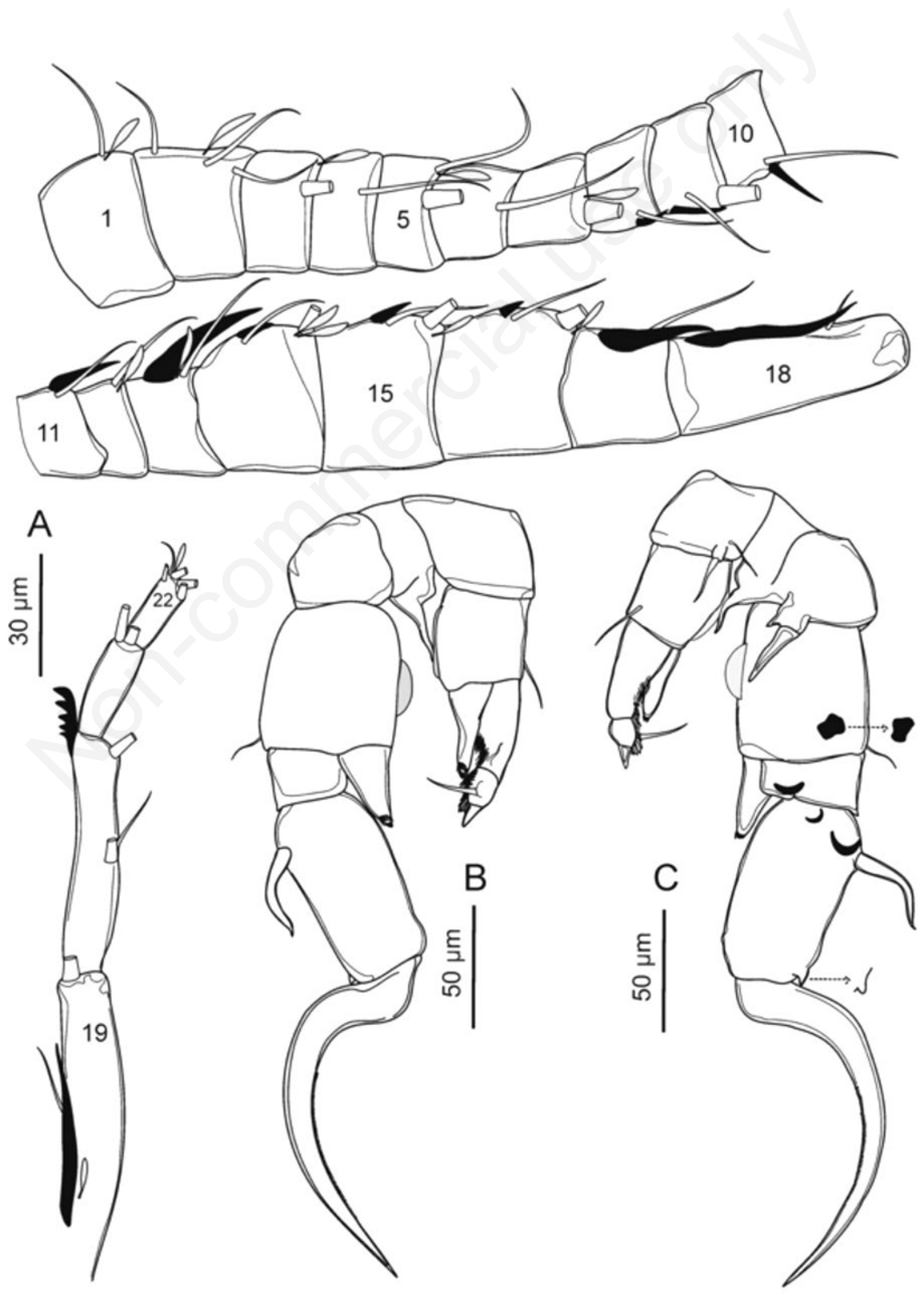

Fig. 3. Allodiaptomus nongensis, new species, male: A) the right antennule; B) P5, anterior view; C) P5, posterior view. 
9 setae. Basis with 2 endites, with 4 setae each; basal exite with one small seta. Enp and Exp reduced to single segment, with 7 and 6 setae, respectively.

Maxilla (Fig. 8D) praecoxal and coxa with 2 endites each: proximal and distal endite with 3 setae each. Basal endite with 3 setae. Enp 2-segmented, with 3 setae each.

Maxilliped (Fig. 8E) praecoxal fused to coxa. Coxa with 4 endites, with 1, 2, 3, and 4 apical setae, respectively. Basis with 3 inner setae and row of small spinules along medial margin. Enp 6-segmented, with setal formula as 2. 3. 2. 2. 2. 4 .

P1-P4 (Fig. 9 A-D) biramous, Exp longer than Enp. P1 with 3-segmented Exp and 2-segmented Enp, P2-P4 with 3-segmented Exp and Enp. Coxa with inner pinnate seta. P4 basis with small seta on outer distal margin. Exp-

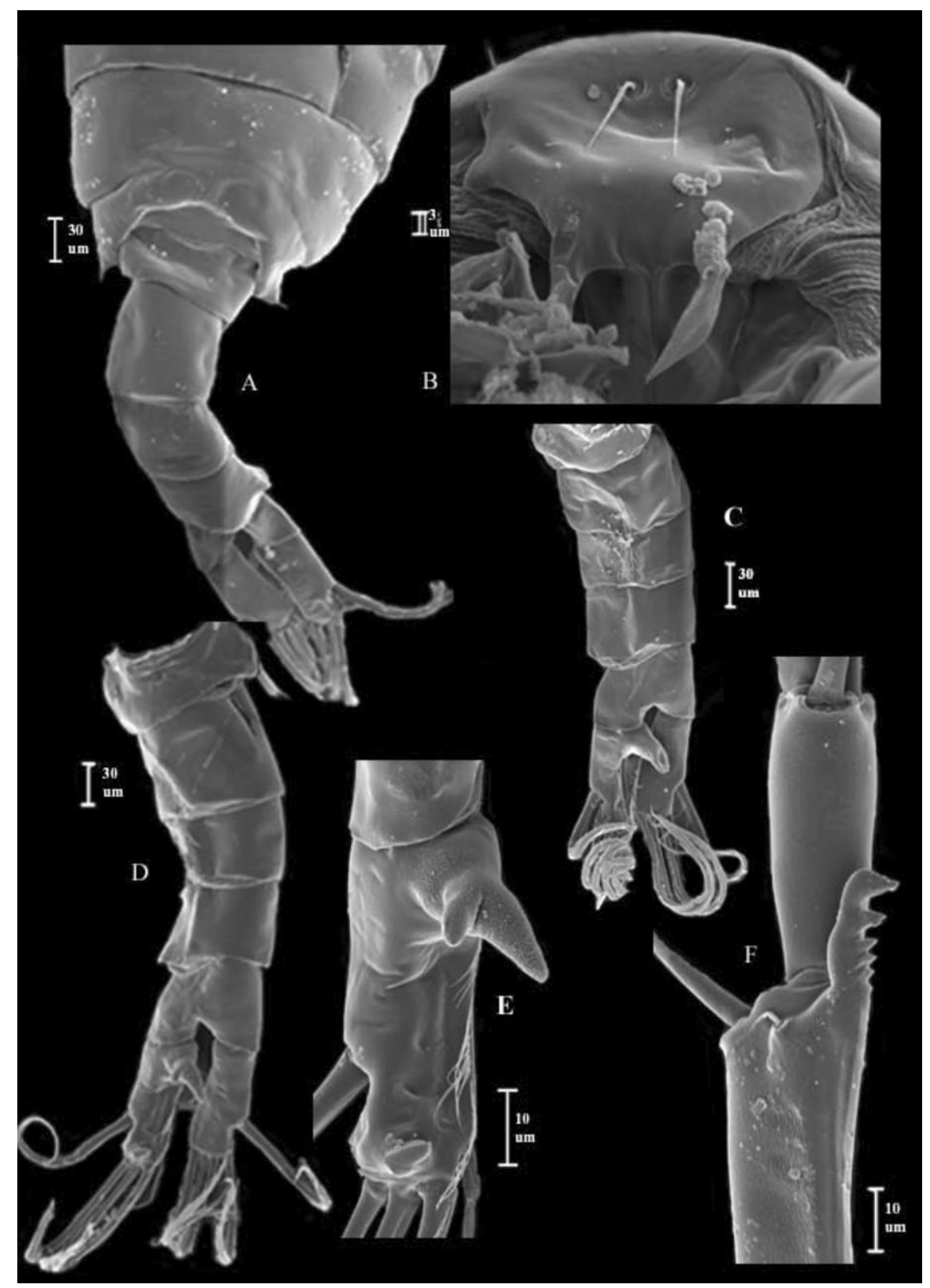

Fig. 4. Allodiaptomus nongensis, new species, SEM photographs of male: A) Pdg 3-5 and urosome, dorsal view; B) rostral spines, anterior view; C,D) urosomites 1-4 and caudal rami, ventral view; E) the right caudal ramus, ventral view; F) antepenultimate segment with comb-like process. 
1-2 with one outer spine and inner pinnate seta except P1 Exp-2 without outer spine. P1 Exp-3 with outer spine, 3 apical pinnate setae and 2 inner pinnate setae. P2-4 Exp3 with outer spine, 3 apical, and 3 inner pinnate setae. Enp-1 with one inner pinnate seta. P1 Enp-2 with 3 inner, 2 apical, and one outer pinnate setae; P2-P4 Enp-2 with 2 inner pinnate setae. P2-P4 Enp-3 with 3 inner, 2 apical, and 2 outer pinnate setae.

Armature formula of P1-P4 as follows (legend: outer- inner seta/spine; outer-apical-inner; Arabic numerals represent setae; Roman numerals represent spines).

\begin{tabular}{lcccccccc}
\hline & Coxa & Basis & \multicolumn{3}{c}{ Exp } & \multicolumn{3}{c}{ Enp } \\
\hline & & & $\mathbf{1}$ & $\mathbf{2}$ & $\mathbf{3}$ & $\mathbf{1}$ & $\mathbf{2}$ & $\mathbf{3}$ \\
\hline P1 & $0-1$ & $0-0$ & I-1 & $0-1$ & I-3-2 & $0-1$ & $1-2-3$ & - \\
\hline P2 & $0-1$ & $0-0$ & I-1 & I-1 & I-3-3 & $0-1$ & $0-2$ & $2-2-3$ \\
\hline P3 & $0-1$ & $0-0$ & I-1 & I-1 & I-3-3 & $0-1$ & $0-2$ & $2-2-3$ \\
\hline P4 & $0-1$ & $1-0$ & I-1 & I-1 & I-3-3 & $0-1$ & $0-2$ & $2-2-3$ \\
\hline
\end{tabular}

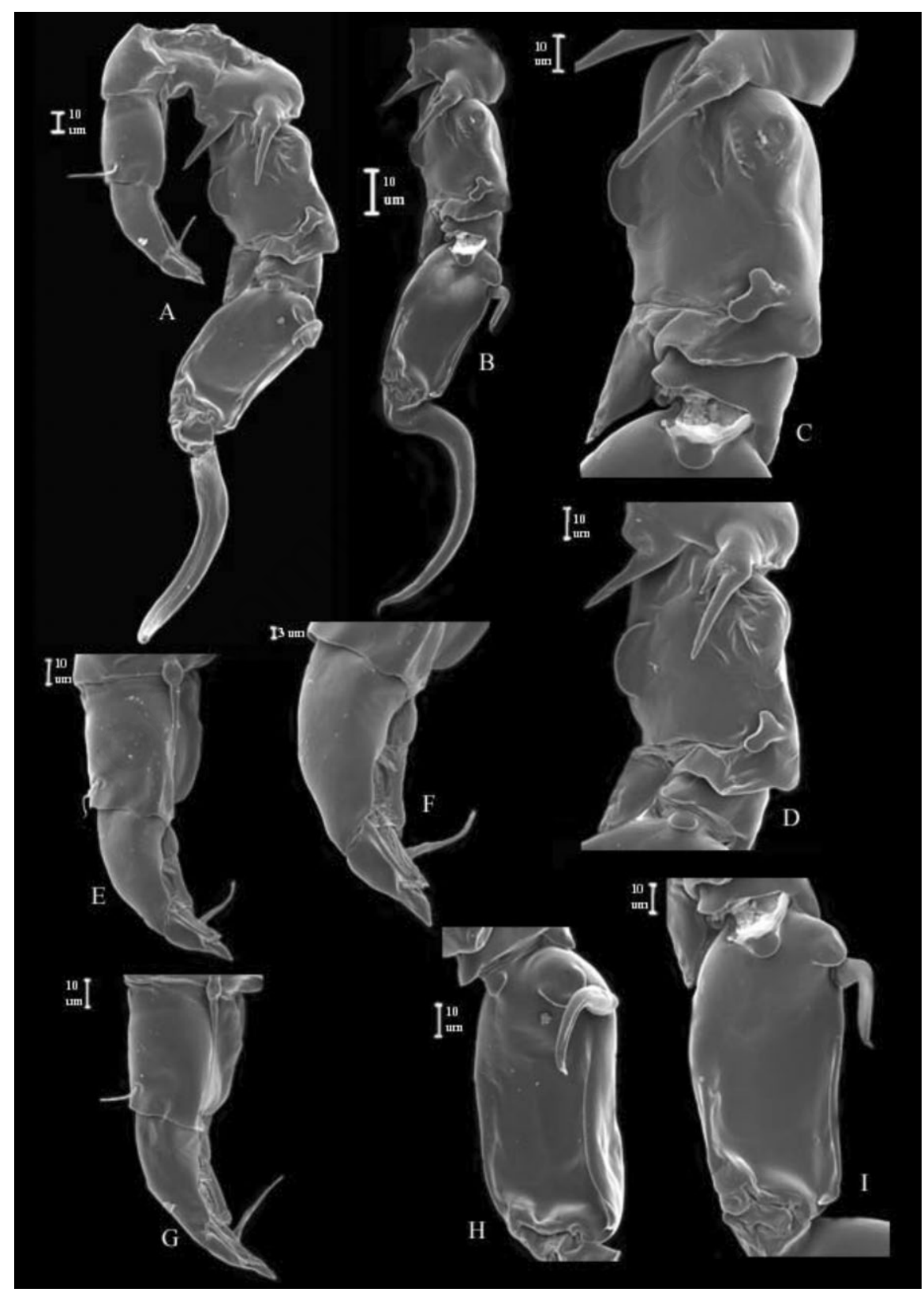

Fig. 5. Allodiaptomus nongensis, new species, SEM photographs of the male P5 in posterior view: A) whole leg; B) the right P5; C,D) the right coxa, basis, Exp-1 and Enp; E-G) the left coxa, basis, Exp and Enp; H) the right Exp; I) the right Exp and Enp. 
P5 (Figs. 7 D-F and 9E) symmetrical. Coxa with stout spine on protuberance at distal outer corner. Basis with thin seta on outer margin, extending about mid-length of Exp-1. Exp 3-segmented. Exp-1 enlarged rectangular-like, more than 2.0 times as long as wide. Exp-2 sub-triangular, with row of strong medial spinules on lateral margins; with outer seta proximally close to Exp-3. Exp-3 small, with two unequal apical setae. Enp 2-segmented, subconical, slightly shorter than Exp-1. Enp-1 shorter than Enp-2. Enp-2 with circular row of spinules apically.

\section{Distribution}

The new species was found in 14 freshwater habitats (9 permanent waters and 5 temporary waters) or 13.6\% of the total localities sampled (103 localities) (Fig. 1B).
They have successfully inhabited a variety of habitats in both rainy and dry seasons, to include rivers, swamps, roadside canals, permanent ponds, temporary ponds and rice fields. Water variables of all localities where $A$. nongensis occurred were $\mathrm{pH}$ 7.1-9.7, temperature 22-35 ${ }^{\circ} \mathrm{C}$, and electric conductivity $10-105 \mu \mathrm{S} \mathrm{cm}{ }^{-1}$. The new species sometimes co-occurred with the following four other diaptomids: Eodiaptomus phuvongi Sanoamuang and Sivongxay, 2004 (in rivers, ponds and swamps), Mongolodiaptomus calcarus (in rivers, swamps, roadside canals, permanent ponds, temporary ponds and rice fields), Vietodiaptomus blachei (Brehm, 1951) (in rivers, swamps, roadside canals, permanent ponds, temporary ponds and rice fields), and Dentodiaptomus sp. (in permanent ponds, temporary ponds and rice fields).

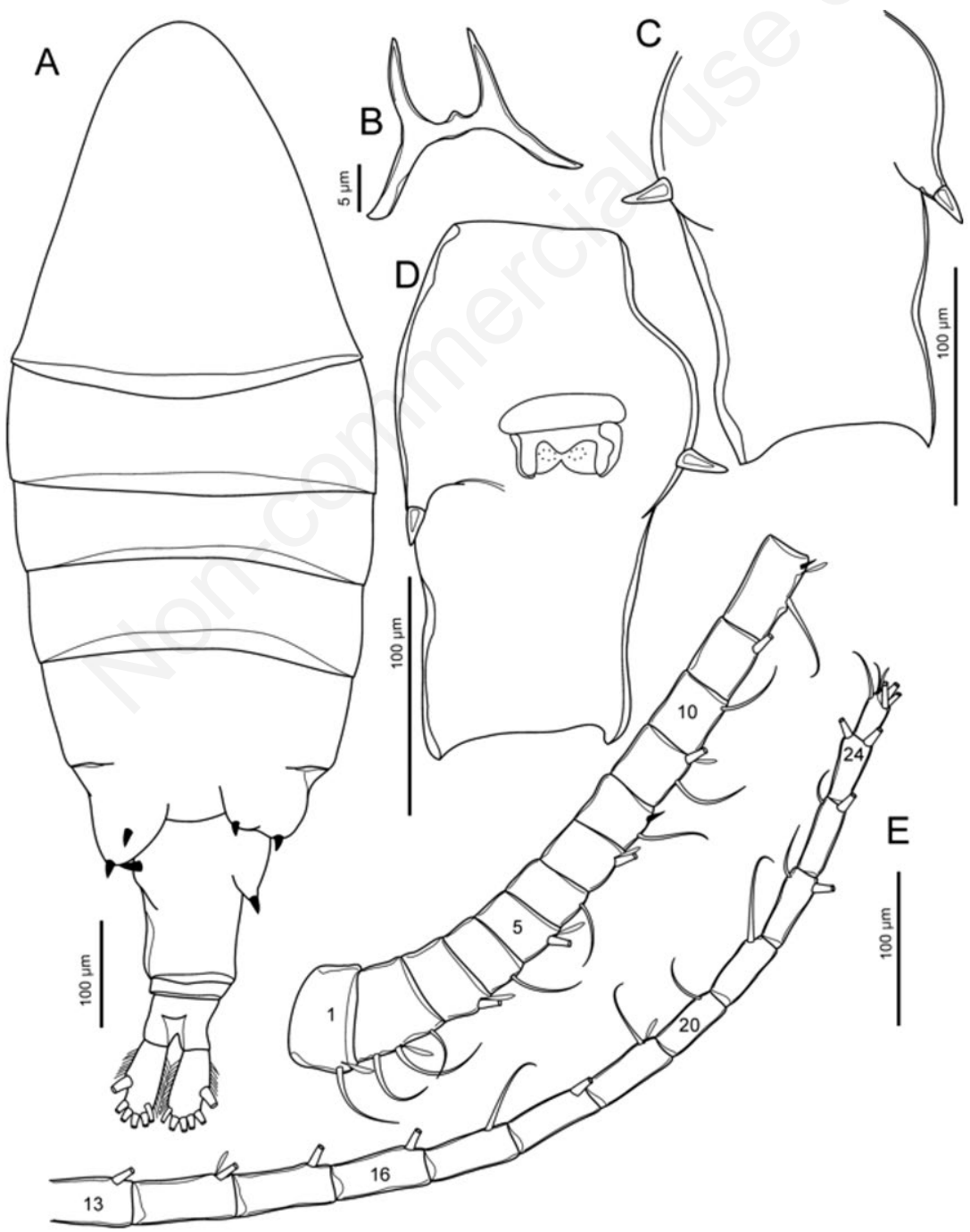

Fig. 6. Allodiaptomus nongensis, new species, female: A) habitus, dorsal view; B) rostrum frontal view; C) genital double-somite, dorsal view; D) genital double-somite, ventral view; E) antennule. 
Allodiaptomus nongensis $\mathrm{n}$. sp. has, to date, been recorded only from Savannakhet Province, Central Laos.

\section{Copepod fisheries}

Copepod fisheries by local Laotian people were observed along the Xe Lanong riverbanks in Savannakhet Province (Fig. 10 A,B). This river is one of the tributaries of the Mekong, and is connected with the Xe Bang Hieng branches before draining into the Mekong (Fig. 1B). Most parts of the Xe Lanong (30-50 m wide, $10 \mathrm{~m}$ deep) pass through Muang Nong District (Fig. 1B; $16^{\circ} 23^{\prime} 4^{\prime \prime N}$, $106^{\circ} 30^{\prime} 15^{\prime \prime} \mathrm{E}$; elevation $285 \mathrm{~m}$ asl), which is where local people harvest a calanoid copepod for human consumption. Unlike most other rivers, the waters of the Xe Lanong are rather still with some slow currents; thus, this river is a perfect habitat for zooplankton.

Allodiaptomus nongensis $\mathrm{n}$. sp. is known as " $\mathrm{Pa}$ Khayong", which means tiny fish, by local people, and it is abundant in the Xe Lanong River and 13 other localities in both temporary and permanent waters, but is so far restricted to Savannakhet Province (Fig. 1B). Populations of this Laotian endemic copepod can be found in the dry season (January until May), but they are more abundant in cooler months (during January and February). A series of man-made copepod traps (Fig. 10 $\mathrm{A}, \mathrm{B})$ are placed by villagers along the shores of the Xe Lanong River in Muang Nong District. These triangularshaped traps are constructed from bamboo poles and coconut palm leaves (Fig. 10C) in order to slow down the water current. The traps are designed to serve as an attractive shelter for the $\mathrm{Pa}$ Khayong. After concentrations of $\mathrm{Pa}$ Khayong are thought to have accumulated, local fishermen stand inside the traps to capture them. A special, home-made plankton net made from a piece of cotton cloth connected to the fisherman's neck is used to filter the Pa Khayong (Fig. 10 D,E). After filtering for 15-20 minutes, a ball of compacted $\mathrm{Pa}$ Khayong (diameter: 9-10 cm) is harvested (Fig. 10F).

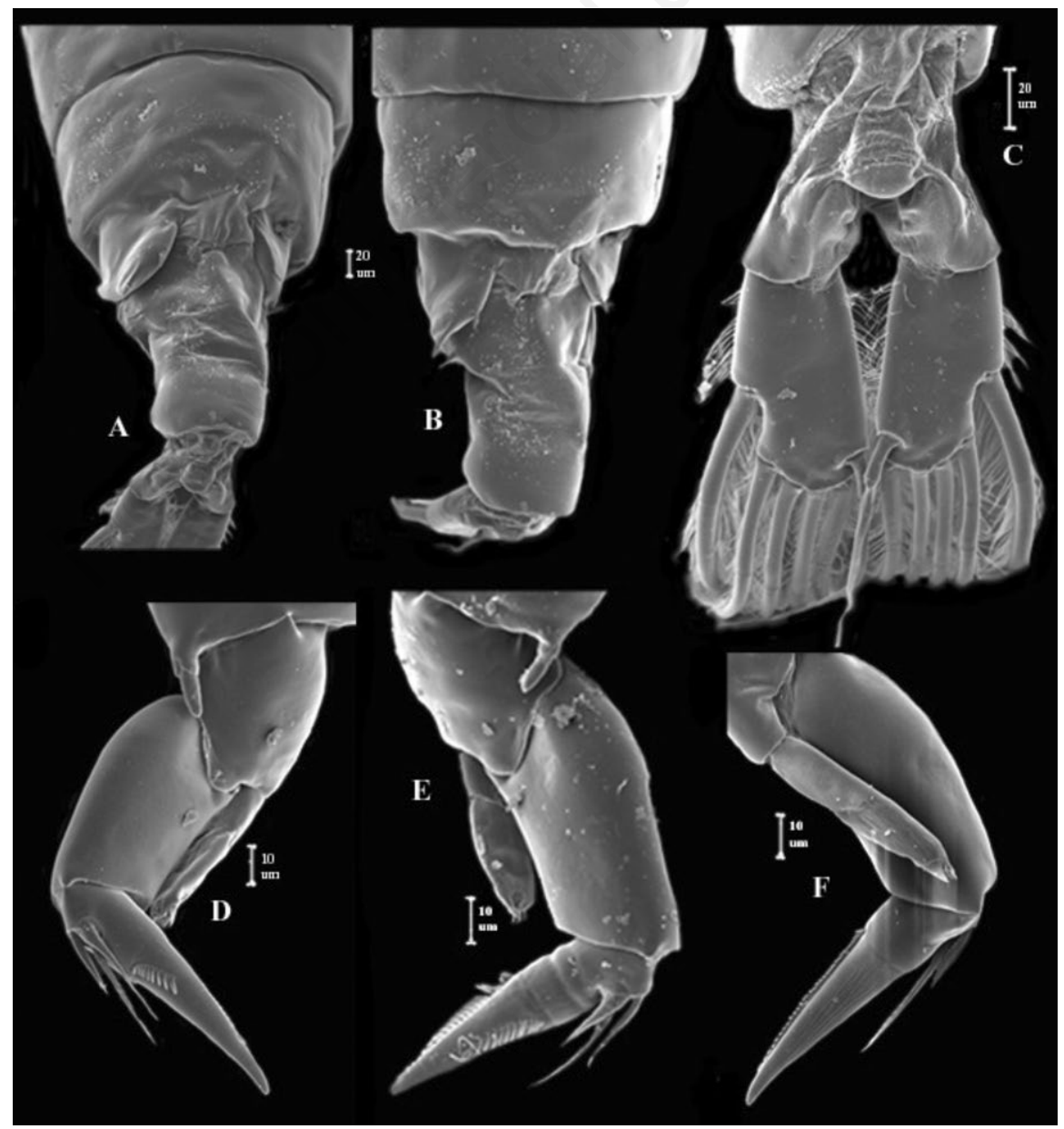

Fig. 7. Allodiaptomus nongensis, new species, SEM photographs of female: A,B) Pdg 3-5 and urosome, dorsal view; C) anal somite and caudal rami, dorsal view; D) the left P5, posterior view; E) the right P5, posterior view; F) the left P5, anterior view. 
Interestingly, high concentrations of $\mathrm{Pa}$ Khayong individuals (body length: $\sim 1 \mathrm{~mm}$ ) all belonging to Allodiaptomus nongensis $\mathrm{n}$. $\mathrm{sp}$. are harvested and consumed by these villagers. The harvested Pa Khayong can be freshly cooked together with chicken eggs to be eaten as omelets. However, some of the Pa Khayong are preserved with salt for long-term preservation and consumption. Fermented Pa Khayong, which looks like a sauce (Fig. 10H), is stored in bamboo tubes (Fig. 10G) and is widely sold in local markets. These tubes containing preserved copepods are renowned throughout
Savannakhet Province, and many are exported and sold outside of Muang Nong District. In 2001, the cost of salted $\mathrm{Pa}$ Khayong in a bamboo tube (approximate volume $\sim 500 \mathrm{~mL}$ ) was 4000 Laotian Kip (about 20 Thai Baht, or 0.6 \$US). Pa Khayong sauce can also be used as a seasoning flavor in different kinds of local dishes. The reason for this copepod consumption by the locals is for nutrition. The Pa Khayong sauce is used to make some unique flavor in the dishes. This traditional consumption of $\mathrm{Pa}$ Khayong has been practiced by several generations of the local people.

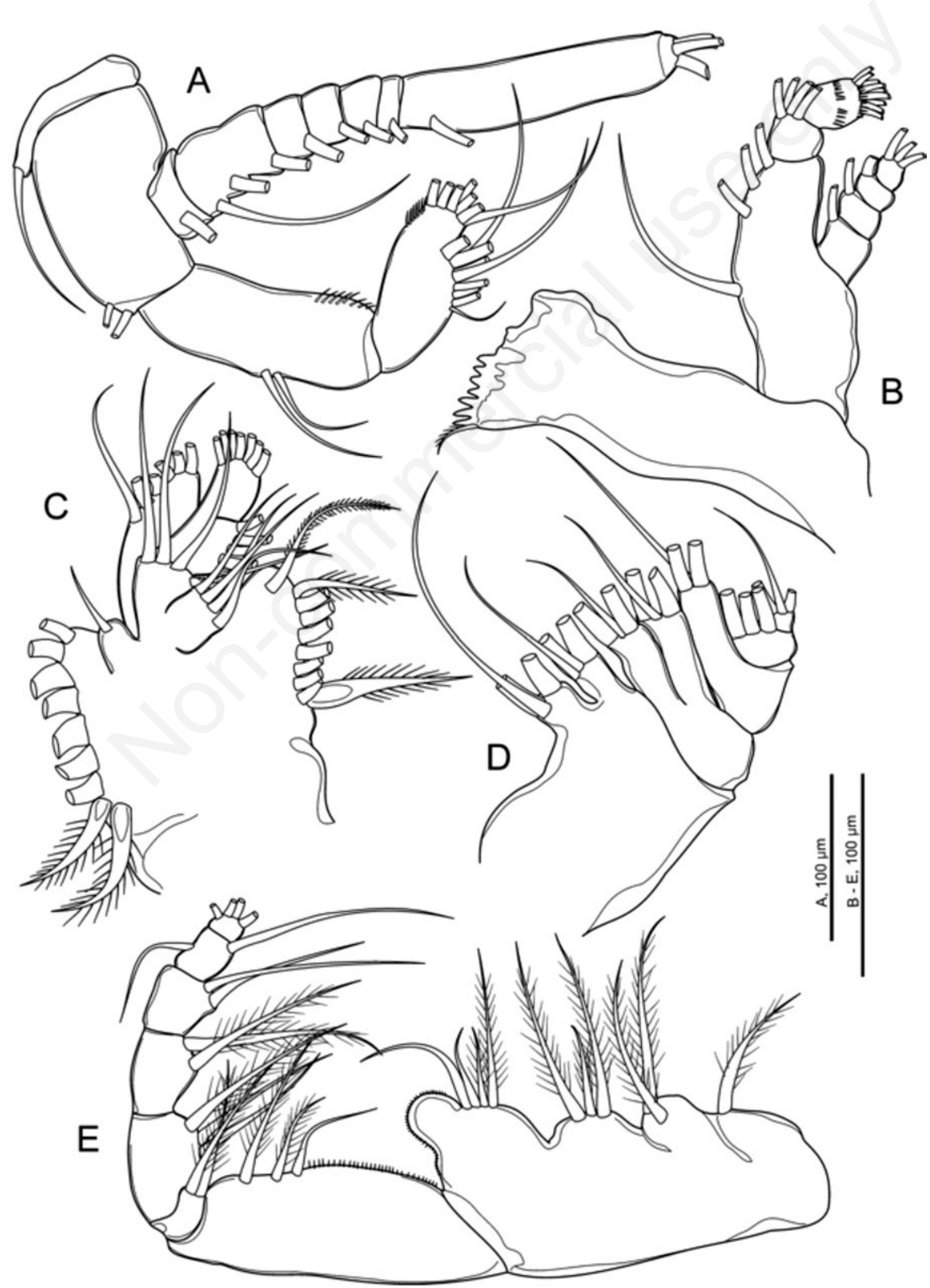

Fig. 8. Allodiaptomus nongensis, new species, female: A) antenna; B) mandible; C) maxillule; D) maxilla; E) maxilliped. 


\section{DISCUSSION}

Allodiaptomus nongensis $\mathrm{n}$. sp. is the third new diaptomid from Laos after Eodiaptomus phuvongi and Mongolodiaptomus mekongensis Sanoamuang and Watiroyram, 2018. These three species were found in the same study area (Sanoamuang and Sivongxay, 2004; Sanoamuang and Watiroyram, 2018). M. mekongensis has a wider distribution and occurs in Laos, Thailand, Cambodia, and Vietnam, while E. phuvongi inhabits Laos (Khammouane and Savannakhet Provinces) and Thailand (Ubon Ratchathani Province). In contrast, Allodiaptomus nongensis $\mathrm{n}$. sp. has, to date, only been identified in Laos (Sanoamuang, 2002; Sanoamuang and Sivongxay, 2004; the present study).

Allodiaptomus nongensis $\mathrm{n}$. sp. fulfils the principal features of the genus Allodiaptomus, as revised by Ranga Reddy (1987) and Ranga Reddy et al., 2000. The genus is characterized by the Exp-2 of the male right P5 having at least two lateral spines, of which the principal one is proximal, and the other is distal. The new species was assigned to the subgenus Allodiaptomus s. str., Allodiaptomus (A.) nongensis $\mathrm{n}$. $\mathrm{sp}$. according to the revision by Ranga Reddy (1987) that outlined the following

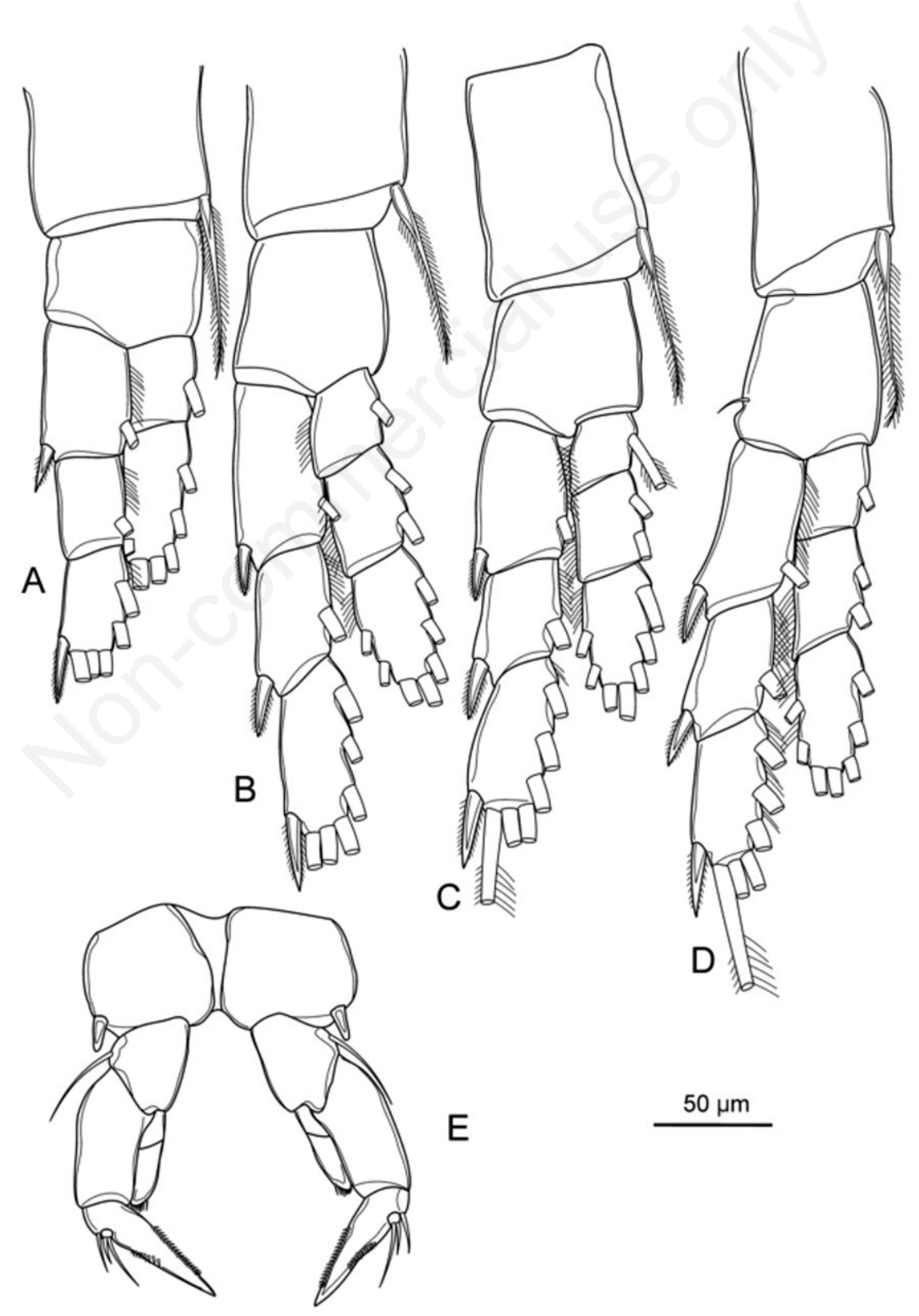

Fig. 9. Allodiaptomus nongensis, new species, female: A) P1; B) P2; C) P3; D) P4; E) P5, posterior view. 
diagnostic characters: (1) P1-P4 Exp-1 with outer spine, (2) P2-P4 Enp-3 with two outer setae, and (3) the principal spine on Exp-2 of the male right P5 is articulated to the proximal margin of the segment. The new species has the closest resemblance to the Indian $A$. satanas by the presence of a comb-like process on the antepenultimate segment, the presence of ventral prominences on the male right caudal ramus, the posterior lobe on the male right P5 coxa is well-developed, the presence of chitinous process on the male right $\mathrm{P} 5$ basis, and the presence of one principal spine at the proximal half, and one accessory spine distally on the male right P5 Exp-2. The female shares with $A$. satanas the following characters: (1) the Pdg 4 has no transverse row of spinules along the postero-dorsal margin, (2) the lateral wings are asymmetrical (left wing triangular, but right wing somewhat bilobed), and (3) the P5 Enp is two-segmented. The males of the new species can be differentiated from other congeners by the right caudal
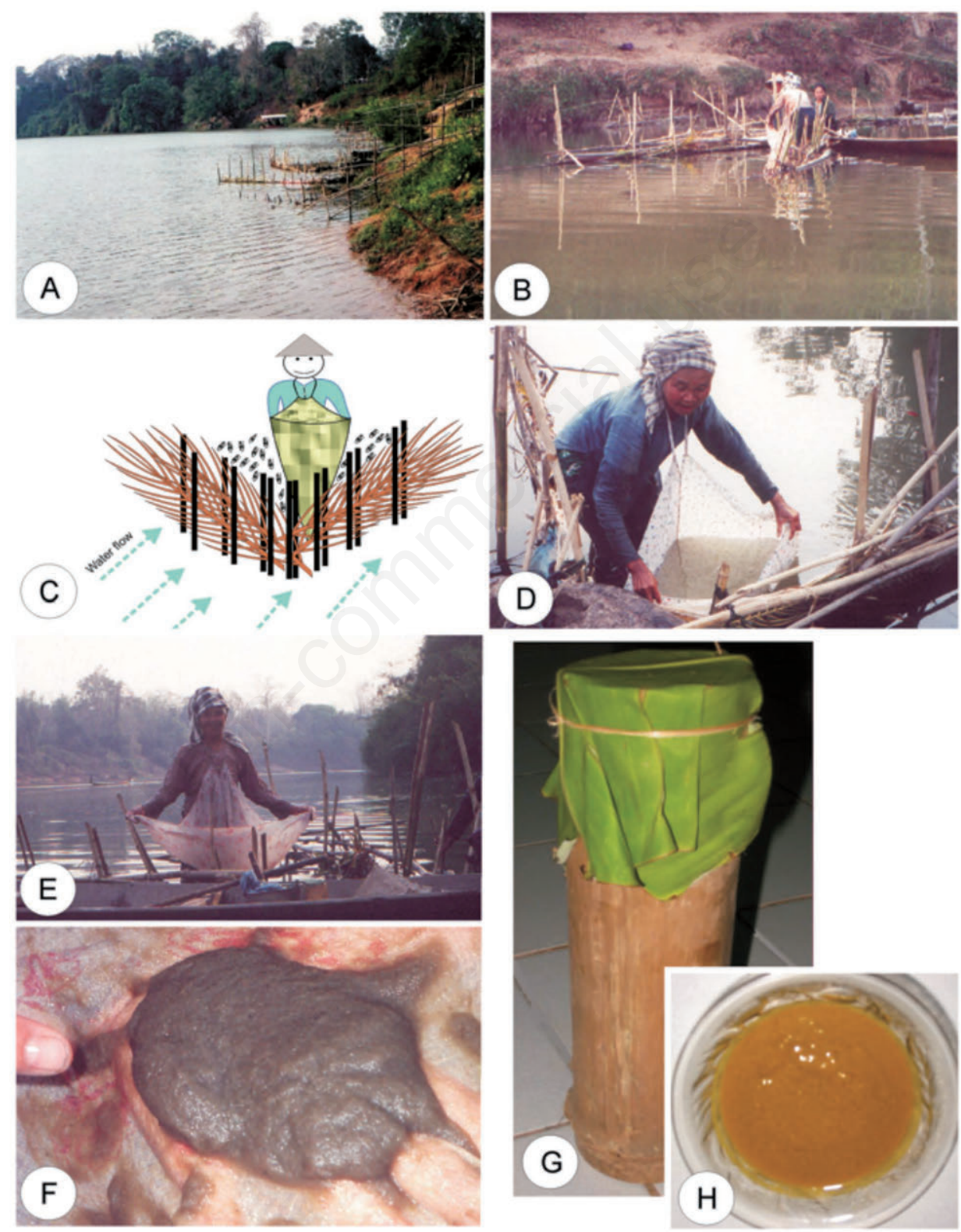

Fig. 10. Copepod (Pa Khayong) fisheries in Xe Lanong River in Muang Nong District, Central Laos. A,B) Man-made copepod traps constructed along the river bank; C) a diagram showing a fisherman catching Pa Khayong; D,E) villagers harvesting Pa Khayong using home-made plankton nets in copepod traps; F) a ball of compacted copepods containing a single species of Allodiaptomus nongensis new species; G) bamboo tubes containing fermented Pa Khayong; H) fermented Pa Khayong. 
ramus has a large, biacuminate, conical process proximal to the inner margin and a semi-circular ridge above insertion of caudal seta IV and V in the new species versus A. satanas, which has a pair of small prominences on the outer margin and two small teeth above insertion of caudal seta II. In the male P5: (1) the intercoxal plate of the new species is produced into a finger-like process on distal inner margin, but with a spherical lobe in A. satanas; (2) the posterior lobe of the right coxa in the new species has an acute process nearby spine insertion, but it is absent in $A$. satanas; (3) the right basis of the new species has inner semi-circular hyaline lamella and a small prominence posterolaterally, but with digitiform hyaline lamella and a pair of small prominences distally and a longitudinal prominence proximally in A. satanas; (4) the right Exp-1 produced into acute process on distal outer margin in the new species, but it is blunt in A. satanas; (5) the right Exp2 in the new species has an outer spherical process inwardly, above the principal spine, and inner margin naked, while $A$. satanas has only an inner process proximally; (6) the left Exp-2 in the new species is serrated with strong spinules on inner margin, but with long hairs in A. satanas; (7) the left Exp-2 of the new species has one apical process similar to Allodiaptomus species, whereas A. satanas has an additional (digitiform) process on inner margin. In the females, (1) the genital double-somite of the new species has a posterolaterally directed process on the right side, but it is absent in A. satanas; (2) the genital spines of the new species are similar in size, whereas the left spine is much larger than the right spine in A. satanas. The coxal spine of the female P5 is stout and blunt in the new species, but it is slender and acute in A. satanas.

The subgenus Allodiaptomus s. str. currently comprises the four following valid species: $A$. (Allodiaptomus) mirabilipes Kiefer, 1936; A. (Allodiaptomus) satanas Brehm, 1952; A. (Allodiaptomus) intermedius Ranga Reddy, 1987; and, A. (Allodiaptomus) nongensis n. sp. (this study). The first three species have been found in India, while $A$. $(A)$ nongensis $\mathrm{n}$. sp. has only been found in Laos. In contrast, the monospecific subgenus Reductodiaptomus, $A$. (Reductodiaptomus) raoi Kiefer, 1936 is widely distributed (known in India, South China, Cambodia, Thailand, and Vietnam), and it also occurs in brackish water (Ranga Reddy, 1987; Tran et al., 2016). Since the description of $A$. (A) mieni is published only in Vietnamese language (Dang and Ho, 1985), its taxonomic status is not discussed here. A comparison of morphologic characters among the five species of the genus Allodiaptomus is given in Tab. 1. All species have the following shared characters in the males: (1) presence of a produced lobe on distal inner coxa or intercoxal plate, and (2) presence of hyaline lamella on inner margin of basis (Ranga Reddy, 1987). In the females, the latter wings on Pdg 5 are asymmetrical, which is probably a common character among Allodiaptomus species. Normally, diaptomids can be identified based on the morphologic differences of males, because the female characters are more or less similar to each other (Ranga Reddy et al., 1998). However, the females of the new species are easily distinguished from its congeners by having a lateral process on the right genital double-somite, and two-segmented P5 Enp (other congeners with 1segmented P5 Enp except $A$. satanas).

The presence of a posterolateral process on the genital somite in female of the new species is similar to those in many species of Mongolodiaptomus, including Mongolodiaptomus malaindosinensis Lai \& Fernando, 1978, M. botulifer (Kiefer, 1974), M. uenoi (Kikuchi, 1936), M. rarus (Ranga Reddy, Sanoamuang \& Dumont, 1998) (this species has been proposed to be transferred from Allodiaptomus to Mongolodiaptomus by Sanoamuang (2002), M. gladiolus, M. loeiensis Watiroyram \& Sanoamuang, 2017, and M. mekongensis. This character is morphologic evidence that demonstrates the close relationship between these two genera. The new species shares the following characters in males with some species of Mongolodiaptomus: (1) the antepenultimate segment with a comb-like process (similar to the mariadvigae species group of Mongolodiaptomus), (2) the right caudal ramus has ventral prominence (similar to all, except $M$. pectinidactylus but unknown for M. gladiolus), (3) the P5 intercoxal plate has produced inner distal margin (similar to the mariadvigae and the mephistopheles species groups, except $M$. mephistopheles), (4) the right P5 coxa has an acute process on distal margin of posterior lobe (similar to M. uenoi and M. mekongensis), (5) the right P5 basis has chitinous prominence [similar to $M$. pectinidactylus, $M$. calcarus (Shen \& Tai, 1965), M. dumonti Sanoamuang, 2001, M. rarus, M. loeiensis, and M. mekongensis], (6) the right P5 Exp-1 has an acute projection on distal outer corner (similar to all, except the gladiolus species group, $M$. pectinidactylus and $M$. birulai) (see Sanoamuang and Watiroyram, 2018).

Allodiaptomus nongensis $\mathrm{n}$. sp. can be distinguished from its congeners by the following characters in males: (1) the antepenultimate segment with a comb-like process (except A. satanas); (2) the right caudal ramus has a large, biacuminate, conical process proximally and a semi-circular ridge ventrally (others smooth, except $A$. satanas with a pair of small prominences and two large stumpy teeth); (3) the intercoxal plate of P5 is digitiform (A. satanas, round; $A$. intermedius, bifid; A. mirabilipes, and A. raoi, triangular); (4) presence of an acute process on posterior lobe of the right P5 coxa (similar to M. uenoi and M. mekongensis; this is the second character shared between the genera Mongolodiaptomus and Allodiaptomus); (5) the right P5 basis with a chitinous process on posterior surface [except 
A. satanas; similar to M. pectinidactylus, M. calcarus (Shen \& Tai, 1965), M. dumonti Sanoamuang, 2001, M. rarus, $M$. loeiensis, and M. mekongensis]; and, (6) the right P5 Exp-1 with acute, produced distal outer corner (except $A$. mirabilipes and A. intermedius).

According to Ranga Reddy et al. (2000), both Allodiaptomus and Mongolodiaptomus are characterized by the male P5 Exp-2 possessing at least two lateral spines. In Allodiaptomus, the principal spine is proximal, while the other one(s) is/are distal. However, in Mongolodiaptomus, the principal spine inserts at the midouter margin, but a small spinous process situates proximally or distally. Therefore, three species previously recognized as A. gladiolus; A. pectinidactylus; and A. calcarus have been transferred to the genus Mongolodiaptomus (Ranga Reddy et al., 2000; Sanoamuang and Watiroyram, 2018). Although the criteria used to distinguish species among Allodiaptomus, Mongolodiaptomus, and Neodiaptomus are well documented (Ranga Reddy, 1987, 2013; Ranga Reddy et al., 1998, 2000; Sanoamuang and Athibai, 2002; Watiroyram and Sanoamuang 2017; and Sanoamuang and Watiroyram, 2018), some taxonomic confusions remain. For example, $A$. rarus has some shared characteristics between Allodiaptomus and Mongolodiaptomus. This species was assigned as a member of Allodiaptomus by the male right P5 Exp-2 with a principal spine somewhat proximal to the middle of the outer margin and a small

Tab. 1. Comparison of morphologic characters among the five species of the genus Allodiaptomus Kiefer, 1936.

\begin{tabular}{|c|c|c|c|c|c|}
\hline \multirow[t]{2}{*}{ Species characters } & \multicolumn{4}{|c|}{ Subgenus Allodiaptomus s. str. } & \multirow{2}{*}{$\begin{array}{l}\text { Subgenus } \\
\text { Reductodiaptomus } \\
\text { A. raoi }\end{array}$} \\
\hline & A. satanas & A. intermedius & A. mirabilipes & A. nongensis n. sp. & \\
\hline \multicolumn{6}{|l|}{ BOTH SEXES } \\
\hline Outer spine on P1-P4 Exp-1* & Presence & Presence & Presence & Presence & Absence \\
\hline $\begin{array}{l}\text { Number of outer seta on P2-P4 } \\
\text { Enp-3* }\end{array}$ & 2 & 2 & 2 & 2 & 1 \\
\hline Principal spine on the right P5 Exp-2* & $\begin{array}{l}\text { Articulated to } \\
\text { margin }\end{array}$ & $\begin{array}{l}\text { Articulated to } \\
\text { margin }\end{array}$ & $\begin{array}{l}\text { Articulated to } \\
\text { margin }\end{array}$ & $\begin{array}{l}\text { Articulated to } \\
\text { margin }\end{array}$ & $\begin{array}{l}\text { Articulated over } \\
\text { posterior surface }\end{array}$ \\
\hline Transverse row of spinules on Pdg 4 & Absence & Presence & Presence & Absence & Presence \\
\hline \multicolumn{6}{|l|}{ FEMALE } \\
\hline Lateral wing & Asymmetrical & Asymmetrical & Asymmetrical & Asymmetrical & Asymmetrical \\
\hline Number of P5 Enp segment & Two & One & One & Two & One \\
\hline P5 & Symmetrical & Asymmetrical & Symmetrical & Symmetrical & Asymmetrical \\
\hline $\begin{array}{l}\text { Genital double-somite with } \\
\text { outgrowth process }\end{array}$ & No & Yes (left side) & No & Yes (right side) & No \\
\hline \multicolumn{6}{|l|}{ MALE } \\
\hline Distal margin of P5 intercoxal plate & Round & Bifid & Triangular & Digitiform & Triangular \\
\hline \multirow{6}{*}{ 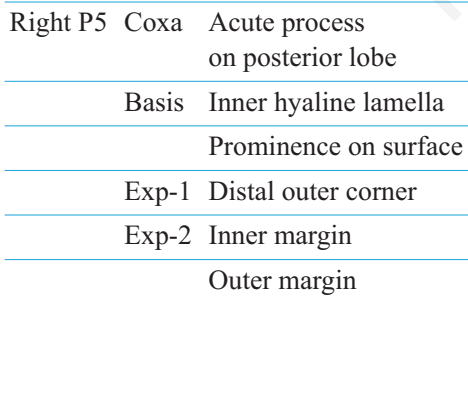 } & Absence & Absence & Absence & Presence & Absence \\
\hline & Digitiform & Elongate & Elongate & Semi-circular & Elongate \\
\hline & Presence & Absence & Absence & Presence & Absence \\
\hline & Blunt & Acute & Acute & Acute & Blunt \\
\hline & With prominence & Smooth & With prominence & Smooth & Smooth \\
\hline & $\begin{array}{l}\text { One proximal } \\
\text { principal and one } \\
\text { distal accessory } \\
\text { spine }\end{array}$ & $\begin{array}{l}\text { One proximal } \\
\text { principal and one } \\
\text { distal accessory } \\
\text { spine }\end{array}$ & $\begin{array}{l}\text { Two principal and } \\
\text { two accessory } \\
\text { spines }\end{array}$ & $\begin{array}{l}\text { One proximal } \\
\text { principal and one } \\
\text { distal accessory } \\
\text { spine }\end{array}$ & $\begin{array}{l}\text { One proximal } \\
\text { principal and one } \\
\text { distal accessory } \\
\text { spine }\end{array}$ \\
\hline Left P5 Exp-2 & Two apical processes & One apical process & One apical process & One apical process & One apical process \\
\hline Process on antepenultimate segment & Serrate & Smooth $* *$ & Smooth** & Serrate & Smooth** \\
\hline Ventral surface of right caudal ramus & $\begin{array}{l}\text { With a pair of small } \\
\text { prominences on } \\
\text { proximal outer } \\
\text { margin and two large } \\
\text { stumpy teeth nearby }\end{array}$ & Smooth & Smooth & $\begin{array}{l}\text { With one large, } \\
\text { biacuminate, conical } \\
\text { process proximally } \\
\text { and one semi-circular } \\
\text { ridge distally }\end{array}$ & Smooth \\
\hline
\end{tabular}

*The subgenus characteristics proposed by Ranga Reddy (1987); **sometimes with serrate process distally. 
spine located distally. However, this characteristic is somewhat difficult to evaluate since the principal spine is located close to the mid-outer margin, which is the typical feature of the genus Mongolodiaptomus. Moreover, Ranga Reddy et al. (1998) noted that A. rarus is more similar to A. calcarus (this species has been transferred to the genus Mongolodiaptomus by Ranga Reddy et al., 2000; Sanoamuang and Watiroyram, 2018) than any of the other congeners as evidenced by the following characters: the antepenultimate segment is produced into a comb-like process, the right caudal ramus with a ventral process, and the right $\mathrm{P} 5$ basis without hyaline membrane on inner margin. After examinations of several males and females of $A$. rarus, the two following identifiable characteristics of the genus Allodiaptomus were observed not to be present in the male P5: the intercoxal plate and the right P5 basis with hyaline lamella on inner margin. Furthermore, the right side of the genital double-somite of the female has a posterolateral process (see Fig. 6-48 in Sanoamuang, 2002), which is common in many species of mongolodiaptomids, but not in allodiaptomids. It is, therefore, appropriate to transfer this taxon to the genus Mongolodiaptomus (Watiroyram and Sanoamuang, 2017; Sanoamuang and Watiroyram, 2018).

Another taxonomic confusion among these genera was observed in Mongolodiaptomus uenoi, which was confused with Allodiaptomus uenoi by Shen and Song (1979). Two species, A. tiruttanii Rajendran, 1979 from South India and A. specillodactylus Shen and Tai, 1964 from South China, are recently recognized as synonyms of Heliodiaptomus cinctus (Gurney, 1907) and A. raoi, respectively (Ranga Reddy, 1987; Walter and Boxshall, 2018). A critical analysis of these taxa using molecular data is required to clarify the phylogenetic relationships among these genera.

The occurrence of an edible, endemic copepod (Allodiaptomus nongensis $\mathrm{n}$. sp.) in the Xe Lanong River, Savannakhet Province is interesting. This species is a source of food for local people, and it is caught by villagers in large numbers in certain parts of the Xe Lanong River and its tributaries in Muang Nong District. However, no quantitative data about the copepod yields are available. Information about the human consumption of the Allodiaptomus copepods in the Xe Lanong River was first reported by the ichthyologist, Maurice Kottelat, but no specific name nor taxonomic data were provided (Kottelat, 2007). Similarly, the consumption of this tiny copepods by Laotian people is similar to that in Northeast Thailand where people cook and consume fairy shrimps (body length: $\sim 15-20 \mathrm{~mm}$ ) as a local delicacy (Sanoamuang and Dumont, 2000; Sriputhorn and Sanoamuang, 2011). Thus, it is known in Southeast Asia that these small crustaceans can be consumed as healthy human foods.

\section{CONCLUSIONS}

One hundred and three freshwater habitats in Central Laos were surveyed for copepods during 2001-2003. A new calanoid copepod, A. nongensis n. sp., is discovered. It appears to be an endemic species restricted to Savannakhet Province and is the third new diaptomid reported in Laos after E. phuvongi, and M. mekongensis. The copepods are harvested in man-made triangular shelters built in the Xe Lanong River, along the shores. Harvest occurs during the dry season between December and May. They can be freshly cooked, fermented or are salted and preserved in bamboo tubes for long-term consumption. These copepod products are widely sold in local markets. This study provides the description of the Laotian endemic copepod that is harvested and consumed by humans. In this paper, $A$. rarus has been proposed to be transferred from Allodiaptomus to Mongolodiaptomus.

\section{ACKNOWLEDGMENTS}

This work was supported by a grant from the Thailand Research Fund under the TRF-CAS Program for Biodiversity DBG6080014. The authors would like to thank Niane Sivongxay for assistance in the field, and Kevin P. Jones for the English corrections.

\section{REFERENCES}

Baird W, 1850. The natural history of the British Entomostraca: I-VIII. The Ray Society, London: 364 pp.

Brehm V, 1951. Cladocera und Copepoda Calanoida von Cambodja. Cybium 6:95-124.

Brehm V, 1952. Ein neuer Diaptomus aus Indien (Neodiaptomus satanas nov. spec.). Zool. Anz. 148:40-43.

Dang NT, Ho TH, 1985. Two new species of Family Diaptomidae from freshwater of Southern Vietnam. J. Biol. 7:40-44.

Gurney R, 1907. Further notes on Indian Freshwater Entomostraca. Rec. Indian Museum. 1: 21-33.

Huys R, Boxshall GA, 1991. Copepod evolution. The Ray Society, London: $468 \mathrm{pp}$.

Kiefer F, 1932. Zwei neue Diaptomiden (Copepoda, Calanoida) aus Indien. Zool. Anz. 100:265-270.

Kiefer F, 1936. Indische Ruderfußkrebse (Crustacea Copepoda) III. Zool. Anz. 113:321-325.

Kiefer F, 1938. Freilebende Ruderfusskrebse (Crustacea, Copepoda) von Formosa. Bull. Biogeogr. Soc. Jap. 8:35-73.

Kiefer F, 1974. Eine neue Diaptomidenart aus Malaysia (Crustacea, Copepoda, Calanoida). Zool. Anz. 192:420-424.

Kikuchi K, 1936. A new species of Diaptomus from Formosa. Proc. Imperial Acad. (Tokyo) 12:198-200.

Kottelat M, 2007. A freshwater diaptomid copepod harvested for human consumption in central Laos. Raffles Bull. Zool.16:355-357.

Kulkarni MR, Pai K, 2016. The freshwater diaptomid copepod 
fauna (Crustacea: Copepoda: Diaptomidae) of the Western Ghats of Maharashtra with notes on distribution, species richness and ecology. J. Limnol. 75:135-143. Doi: 10.4081/jlimnol.2015.1269

Lai HC, Fernando CH, 1978. The freshwater Calanoida (Crustacea, Copepoda) of Singapore and peninsular Malaysia. Hydrobiologia 61:113-127.

Lin Q, Han BP, 2012. Diversity and community structure of zooplankton in reservoirs in South China, p. 3-28. In: BP Han, Z Liu (eds.), Tropical and sub-tropical reservoir limnology in China. Springer Science + Business Media, New York.

Phan DD, Nguyen VK, Le TNN, Dang NT, Ho TH, 2015. Identification handbook of freshwater zooplankton of the Mekong River and its tributaries. Mekong River Commission, Vientiane: 207 pp.

Rajendran M, 1979. Allodiaptomus tiruttanii, a new species of Copepoda (Diaptomidae) from South India. Indian Zool. 3:5-8.

Ranga Reddy Y, 1987. A taxonomic revision of the genus Allodiaptomus Kiefer (Copepoda, Calanoida), including the description of a new species from India. Crustaceana 52:113-134

Ranga Reddy Y, 1994. Copepoda: Calanoida: Diaptomidae. Key to the Genera Heliodiaptomus, Allodiaptomus, Neodiaptomus, Phyllodiaptomus, Eodiaptomus, Arctodiaptomus and Sinodiaptomus. Guides to the Identification of the Microinvertebrates of the Continental Waters of the World 5. SPB Academic Publishing, The Hague: 221 pp.

Ranga Reddy Y, 2013. Neodiaptomus prateek n. sp., a new freshwater copepod from Assam, India, with critical review of generic assignment of Neodiaptomus spp. and a note on diaptomid species richness (Calanoida: Diaptomidae). J. Crustacean Biol. 33:849-865.

Ranga Reddy Y, Das PK, 1981. A redescription of Neodiaptomus satanas Brehm, 1952 (Copepoda, Calanoida) with critical comments on its present taxonomic status. Crustaceana 41:1-9.

Ranga Reddy Y, Sanoamuang L, Dumont HJ, 1998. A note on the Diaptomidae of Thailand, including redescription of three species and description of a new species (Copepoda, Calanoida). Hydrobiologia 361:201-223.

Ranga Reddy Y, Sanoamuang L, Dumont HJ, 2000. Amended delimitation of Mongolodiaptomus against Neodiaptomus and Allodiaptomus and redescription of the little known Mongolodiaptomus uenoi (Kikuchi, 1936) from Thailand (Copepoda: Calanoida: Diaptomidae). Hydrobiologia 418:99-109.

Sanoamuang L, 1999. Species composition and distribution of freshwater Calanoida and Cyclopoida (Copepoda) of northeast Thailand. In: F.R. Schram and JC von Vaupel
Klein (eds.), Crustaceans and the Biodiversity Crisis. Proceedings of the Fourth International Crustacean Congress. Brill, Leiden, 1: 217-230.

Sanoamuang L, 2001. Mongolodiaptomus dumonti n. sp., a new freshwater copepod (Calanoida, Diaptomidae) from Thailand. Hydrobiologia 448:41-52.

Sanoamuang L, 2002. Freshwater zooplankton: Calanoid Copepods in Thailand. Klangnanatham Publishers (Khon Kaen), Thailand: 159 pp.

Sanoamuang L, Athibai S, 2002. A new species of Neodiaptomus (Copepoda, Diaptomidae) from temporary waters in northeast Thailand. Hydrobiologia 489:71-82.

Sanoamuang L, Dumont HJ, 2000. Fairy shrimp: a delicacy in northeast Thailand. Anostracan News 8(1):3.

Sanoamuang L, Sivongxay N, 2004. Description of Eodiaptomus phuvongi, new species, (Copepoda, Calanoida) from Thailand and Laos. Crustaceana 77:1223-1236.

Sanoamuang L, Watiroyram S, 2018. Mongolodiaptomus mekongensis, a new species of copepod (Copepoda, Calanoida, Diaptomidae) from temporary waters in the floodplain of the lower Mekong River Basin. Raffles Bull. Zool. 66:782-796.

Sars GO, 1903. An account of the Crustacea of Norway with short descriptions and figures of all the species: IV. Copepoda Calanoida. Bergen Museum, Bergen: 177 pp.

Shen CJ, Lee FS, 1963. The estuarine Copepoda of Chiekong and Zaikong Rivers, Kwangtung Province, China. Acta Zootax. Sin. 15:571-596.

Shen CJ, Song DX, 1979. Calanoida, In: Fauna Sinica. Crustacea. Freshwater Copepoda. Science Press, Peking: $450 \mathrm{pp}$.

Shen CJ, Tai AY, 1964. Descriptions of eight new species of freshwater Copepoda (Calanoida) from the delta of the Pearl River, South China. Acta Zool. Sin. 16:225-246.

Shen CJ, Tai AY, 1965. Descriptions of six new species of freshwater copepods chiefly from the Pearl River delta, South China. Acta Zootax. Sin. 2:126-140.

Sriputhorn K, Sanoamuang L, 2011. Fairy shrimp (Streptocephalus sirindhornae) as live feed improve growth and carotenoid contents of giant freshwater prawn Macrobrachium rosenbergii. Int. J. Zool. Res. 7:138-146.

Tran DL, Dang NT, Ho TH, 2016. An annotated checklist of the family Diaptomidae Sars, 1903 (Copepoda, Calanoida) in Vietnam. Tap Chi Sinh Hoc. 38:384-399.

Walter TC, Boxshall G, 2018. World of Copepods database. Accessed at http://www.marinespecies.org/copepoda on 2018-11-15

Watiroyram S, Sanoamuang L, 2017. A new species of Mongolodiaptomus Kiefer, 1938 from northeast Thailand and a key to the species (Crustacea: Copepoda, Calanoida, Diaptomidae). ZooKeys 710:15-32. 